\title{
Biotech patent landscapes: a reflection of global innovation?
}

\author{
"The strength of the biotechnology industry in a country is therefore \\ one of the good indicators for the country's overall innovative \\ strength and its level of economic development."
}

Keywords: biotechnology $\bullet$ competitiveness $\bullet$ innovation metrics $\bullet$ patent statistics $\bullet$ stage of development

It is well accepted that innovations are a driver for economic prosperity [1,2]. The types of innovation that are essential for a country's economy are dependent on the development stage of that country. Most likely, developing countries rely more on low-tech innovations whereas highly advanced countries on the other end of the development scale depend on high-tech innovations to foster their economy. Biotech is a high-tech industry that is dependent on a number of factors such as an excellent educational system, good infrastructure, a well-oiled financial market and a reliable regulatory environment. These and other factors are used to generate so-called innovation indices to measure a country's innovation performance. These indices are published annually, thereby allowing to monitor a country's performance over time. The most prominent innovation or competitiveness indices are the World Economic Forum (WEF) Global Competitiveness Report [3], the Global Innovation Index [4] surveyed and published by the Cornell University, INSEAD Business School and the World Intellectual Property Organization (WIPO), and the Innovation Union Scoreboard [5], a comparative assessment of innovation strength of the EU member states which is published by the European Commission.

\section{The basis for measuring innovation}

These innovation indices are based on several pillars which may include institutions, infrastructure, macroeconomic environment, health, education, market efficiency, financial market, technology readiness, market size, business sophistication and last but not least innovation [3]. Measurement of innovation invariably includes the counting of patent documents originating from one specific country. The approach to counting these documents might vary considerably among all indices. One report lists the counting of the patent applications filed under the Patent Cooperation Treaty (PCT) per million population [3]. Another report takes into account the number of patent families filed in at least three offices per gross domestic product (GDP) [4] or the number of PCT patent applications per GDP [5]. In any case, the counting of patent documents is a crucial measurement for innovation output, despite the fact that innovations are not congruent with inventions. No doubt, in high-tech fields, an invention serves always as the starting point for an innovation. However, innovation involves the successful introduction of the invention to the market as well. Despite this inconsistency, all innovation and competitiveness indicators use the number of inventions as a measurement of innovation strength, which is presumed to be a reasonable approximation for innovation.

\section{Patent information beyond the counting of patents}

Patents information can of course provide more indicators concerning the innovative competitiveness of a country than just the sheer number of patent documents over time. For example, information on the origin of the inventors on biotech patents worldwide provides an indication on the excellency of the higher education system in life sciences when

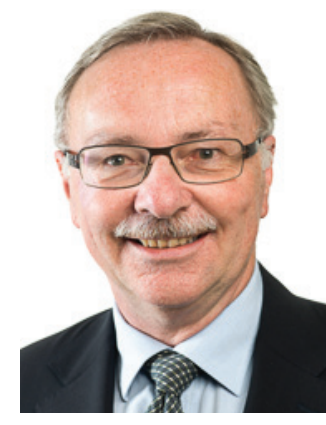

Heinz Mueller

Swiss Federal Institute of Intellectual Property, Stauffacherstrasse 65, 3003 Bern, Switzerland Tel.: +41377 7368 heinz.mueller@ipi.ch 
the size of the country (population or GDP) is taken into account. Furthermore, statistical evaluation of the origin of inventors using the biotech patents count indicates the openness and attractiveness of a country for a highly educated international workforce. Furthermore, statistical evaluation of the jurisdictions in which patent family members were granted allows an estimate about the importance of the different markets for the country concerned. The distribution of family members around the world can then be compared with the distribution seen in countries with similar economies.

\section{The hype is over}

It is interesting to note that the number of biotech patent documents published worldwide has decreased slightly, by about $1-4 \%$ annually between 2011 and 2014 . At the European Patent Office, it decreased between 18\% in 2011 and $4 \%$ in 2014. Likewise, the USA saw a contraction of $2 \%$ in 2011, $10 \%$ in 2012 and 2013, and a steady development in 2014. This trend in biotech patenting in highly developed countries does probably not mean that biotech is less attractive for pharma and its investors and thus less important for a given economy. Rather, these data could indicate that the worldwide biotech hype is over and the industry has become more mature and sustainable. Furthermore, the focus has shifted somewhat from 'patenting everything' to 'patenting the right thing' and, consequently, saving time and money. In fact, it has been reported that the global biotechnology industry reached new peaks in 2014, setting records on virtually every major financial metric, including revenues, profitability and capital raised [6]. Thus, the decreasing trend in biotech patenting does not appear to be an indication of the decreasing importance of the industry. The biotech patenting activities in a given country might still be an indicator for its competitiveness and inventiveness.

\section{Does the biotech patent information reflect innovation \& competitiveness of a country?}

A count of the biotech patents documents published in 2014 shows that there is, as expected, a large difference between Brazil, Russia, India, China and South Africa (BRICS) and the advanced economies typical of Europe, the USA, China, Japan or Korea. The number of pub-

\section{References}

1 Joseph A. Schumpeter. Capitalism, Socialism and Democracy. Routledge, London, UK (1943).

2 Antonelli C. The Economics of Innovation, New Technologies, and Structural Change. Routledge, London, UK (2003).

3 World Economic Forum. The Global Competitiveness Report 2014-2015.

www.weforum.org/reports/global-competitiveness lished biotech patent documents per capita in 2014 was about 20-40-times less in the BRICS countries than in the developed countries. Among the BRICS countries, Russia was best in class with 'only' about ten-times fewer patent documents than the developed countries. Overall, the USA was the champion in biotech patenting contributing almost $30 \%$ to the worldwide count. However, if calculated per capita, the USA was behind other countries such as Israel and Korea. The overall winners seem to be the small high-tech countries such as Switzerland and Denmark. Japan, Germany, the UK and France are performing in mid range.

Comparing these rankings with the global innovation and competitiveness indices shows approximately the same picture. Although the absolute ranking of the countries might differ slightly from index to index, the rankings are similar to the best in biotechnology performance rankings per capita. The strength of the biotechnology industry in a country is therefore one of the good indicators for the country's overall innovative strength and its level of economic development. This is not surprising since biotechnology and other high-tech industries will only prosper in a country with an excellent education system including universities, a well-developed capital market and political and social stability. Small highly developed countries with a well-established infrastructure thus have an advantage over large, fast growing and less well organized countries. No wonder Switzerland and Denmark are leading the pack as far as biotech is concerned, while the BRICS are still lacking far behind. However, as the latter develop and become more organized, fight corruption and social unrest and establish educational systems that foster sciences, they might catch up rapidly and build up a strong biotechnology industry.

Financial \& competing interests disclosure

The author has no relevant affiliations or financial involvement with any organization or entity with a financial interest in or financial conflict with the subject matter or materials discussed in the manuscript. This includes employment, consultancies, honoraria, stock ownership or options, expert testimony, grants or patents received or pending, or royalties.

No writing assistance was utilized in the production of this manuscript.

4 Cornell University, INSEAD, World Intellectual Property Organization (WIPO). The Global Innovation Index 2014. www.globalinnovationindex.org/content.aspx?page

5 European Commission. Innovation Union Scoreboard 2015. http://ec.europa.eu/growth/industry/innovation

6 EY, London. Biotechnology Industry Report 2015: Beyond borders: reaching new heights. www.ey.com/Publication/vwLUAssets 